\title{
The Role of Radiotherapy in the Treatment of Primary or Recurrent Desmoid Tumors and Long-Term Results
}

\author{
Şefika Arzu Ergen ${ }^{1}$, Elif Eda Tiken ${ }^{1}$, Didem Çolpan Öksüz ${ }^{1}$, Fazilet Öner Dinçbaş ${ }^{1}$, Sergülen Dervişoğlu ${ }^{2}$, \\ Nil Molinas $\mathrm{Mandel}^{3}$, Murat Hiz ${ }^{4}$, Sedat Koca ${ }^{1}$
}

${ }^{1}$ Department of Radiation Oncology, Istanbul University Cerrahpasa School of Medicine, Istanbul, Turkey
2Department of Pathology, Istanbul University Cerrahpasa School of Medicine, Istanbul, Turkey
${ }^{3}$ Department of Medical Oncology, Istanbul University Cerrahpasa School of Medicine, Istanbul, Turkey.
${ }^{4}$ Department of Orthopedic Surgery, Istanbul University Cerrahpasa School of Medicine, Istanbul, Turkey.

Background: Desmoid tumors are uncommon and benign mesenchymal neoplasms. The optimal treatment of patients with desmoid tumors is still controversial. Surgery is the primary treatment for locally invasive or recurrent desmoid tumors. Also, radiotherapy is a treatment option for patients at high risk for local failure such as those with positive margins or recurrent and unresectable tumors.

Aims: To report our institutional experience and longterm results of patients with desmoid tumors who received radiotherapy.

Study Design: Retrospective cross-sectional study.

Methods: Between 1980 and 2009, 20 patients who received radiotherapy (RT) in our institution were analyzed. The majority of patients $(80 \%)$ were referred with a recurrent tumor after previous surgery. Thirteen patients underwent marginal resection, 4 had wide local excision and 3 patients had only biopsy. Resection margin was positive in $15(75 \%)$ patients. All patients received radiation therapy. The median prescribed dose was 60 Gy. Five patients received less than 54 Gy.

Results: The median follow-up time was 77.5 months (28-283 months). Nine patients developed local recurrence after RT. Seven local failures $(78 \%)$ were in field. Time to local recurrence ranged from 3-165 months (median 33 months). The 2-5 year local control (LC) rates were $80 \%$ and $69 \%$, respectively. On univariate analysis, the 5 year local control rate was significantly better in the patients treated with $\geq 54$ Gy than in patients who received $<54$ Gy $(\mathrm{p}=0.023)$. The most common acute side effect was grade 1-2 skin toxicity. As a late side effect of radiotherapy, soft tissue fibrosis was detected in 10 patients and lymphangitis was seen in 1 patient. One patient developed radiation-induced sarcoma.

Conclusion: According to our results, radiotherapy is especially effective in recurrent disease and provides a high local control rate in the patients received more than $54 \mathrm{~Gy}$. Keywords: Aggressive fibromatosis, desmoid tumor, local control, radiotherapy
Desmoid tumor or aggressive fibromatosis are characterized as monoclonal fibroblastic proliferations and originate from deep mesenchymal tissues (1). It is a rare non-malignant soft tissue neoplasm. $(2,3)$. The etiology of the disease is unknown, but trauma, postsurgical scar, endocrine and genetic causes are being considered as possible risk factors for the development of desmoid tumors $(3,4)$. Desmoid tumors have a wide spectrum of heterogeneity in clinical attitude, but they usually have an infiltrative growth and locally aggressive behavioral pattern, and do not distantly metastasize $(2,5,6)$. These tumors have been classified as intermediate grade sarcomas since they are locally invasive and local recurrence rates are very high after wide local resection $(7,8)$.

The optimal management of desmoid tumors is still controversial. Classically, surgical excision is the main treatment modality for locally invasive or recurrent desmoid tumors. On the 
other hand, while this tumor has deep infiltration and is nonencapsulated, resection with a negative surgical margin is generally impossible (7). Also, they spread along the fascial planes. A high local recurrence rate is reported in several studies (9-12). Therefore, in the retrospective studies, radiotherapy (RT) has been suggested for its local control benefits. It reduces the incidence of local recurrence for these patients and it may control unresectable disease $(13,14)$. Concurrently, some authors have reported a wait and see policy for stable and asymptomatic lesions, while others have recommended chemotherapy or systemic therapy for unresectable lesions $(2,7,15,16)$.

In this study, we reported our institutional experience and the long-term results of patients with desmoid tumors who received radiotherapy.

\section{MATERIALS AND METHODS}

Between 1980 and 2009, 25 patients referred to our institution with the diagnosis of desmoid tumor. Twenty of them who received radiotherapy were retrospectively reviewed. Patients' characteristics, treatment details and results and long-term follow-up were evaluated. Twelve patients were female and 8 patients were male. The median age was 29 years (10-80 years) and 7 patients were under 18 years-old. The location of the tumors were as follows: lower extremities in 9 patients, upper extremities in 4 patients, thoracic wall in 4 patients, retroperitoneal regions in 2 patients and neck in 1 patient. Mean tumor size was $9 \mathrm{~cm}(3-19 \mathrm{~cm})$. Ten $(50 \%)$ of the tumors were $\geq 10 \mathrm{~cm}$ at the largest point. Sixteen patients $(80 \%)$ were referred with recurrent tumor after previous surgery, eight patients were referred to us after the second, 3 after the third and 5 after the fourth recurrence. Among the 20 patients, 13 patients underwent marginal resection, 4 had wide local excision and 3 patients had only biopsy. Resection margin was positive in $15(75 \%)$ patients.

Two patients with unresectable tumor received definitive RT. Only one patient had preoperative RT as limb sparing surgery was difficult and the patient did not agree to amputation. Seventeen patients had postoperative RT. Eighteen patients were treated with sole external beam radiotherapy (EBRT). In one patient, brachytherapy was used as a boost (30 Gy) after $36 \mathrm{~Gy}$ external RT. Brachytherapy was used as a primary treatment modality (46 Gy) in one case. Most of the patients were irradiated by 2 dimension (D) plans with two parallel opposing beams. RT portals included the full tumor extent and/or surgical incision or tumor bed with a margin to $2 \mathrm{~cm}$ radial and $5 \mathrm{~cm}$ longitudinal directions. Seven patients were treated using 3D techniques. After 2000, the clinical target volume (CTV) included the gross tumor volume or tumor bed with a $2 \mathrm{~cm}$ margin for the radial and $3-5 \mathrm{~cm}$ in the upper and lower directions and was adapted to anatomic barriers. The planning target volume was created by giving a $1 \mathrm{~cm}$ margin to CTV. External RT was delivered with Co-60 (Cis. Bio. Int., Gif sur Yvette, France) or 4-15 MV linear accelerator (GE Medical Systems, Buc, France). The median total RT dose was 60 Gy (range, 40-64 Gy) in 1.8-2.0 Gy daily fractions. Five patients received less than $54 \mathrm{~Gy}$. Patient characteristics and treatment details are summarized in Table 1.

All patients were followed-up regularly with a physical examination every 3-6 months for 5 years and yearly thereafter.

TABLE 1. Patient characteristics and treatment data

\begin{tabular}{|c|c|}
\hline Characteristic & $\mathrm{n}$ \\
\hline Total number of patients & 20 \\
\hline \multicolumn{2}{|l|}{ Gender } \\
\hline Male & 8 \\
\hline Female & 12 \\
\hline Median age & $29(10-80)$ \\
\hline \multicolumn{2}{|l|}{ Tumor localization } \\
\hline Lower extremity & 9 \\
\hline Upper extremity & 4 \\
\hline Thorax & 4 \\
\hline Retroperitoneal & 2 \\
\hline Neck & 1 \\
\hline Tumor size (median) (cm) & $9(3-19)$ \\
\hline$<10 \mathrm{~cm}$ & 10 \\
\hline$\geq 10 \mathrm{~cm}$ & 10 \\
\hline \multicolumn{2}{|l|}{ Surgery } \\
\hline Marginal resection or wide local excision & 17 \\
\hline Intralesional excision & 3 \\
\hline \multicolumn{2}{|l|}{ Surgical margin status } \\
\hline Positive/close & 15 \\
\hline Negative & 5 \\
\hline \multicolumn{2}{|l|}{ Indication of RT } \\
\hline At recurrence/postoperative & 17 \\
\hline Primary & 2 \\
\hline Preoperative & 1 \\
\hline \multicolumn{2}{|l|}{ Radiotherapy } \\
\hline EBRT & 19 \\
\hline Brachytherapy & 2 \\
\hline Median RT dose & 60 Gy (40-64 Gy) \\
\hline$<54$ Gy & 5 \\
\hline$\geq 54 \mathrm{~Gy}$ & 15 \\
\hline EBRT: external beam radiotherapy; $R T$ : radiothera & \\
\hline
\end{tabular}


TABLE 2. Details of patients who developed recurrence

\begin{tabular}{|c|c|c|c|c|c|c|c|c|c|}
\hline Patients & $\begin{array}{c}\text { Sex/ } \\
\text { Age }(y)\end{array}$ & $\begin{array}{l}\text { Tumor } \\
\text { location }\end{array}$ & $\begin{array}{l}\text { Primer Tumor } \\
\text { Size }(\mathrm{cm})\end{array}$ & $\begin{array}{c}\text { Margin } \\
\text { Status }\end{array}$ & $\begin{array}{l}\text { Previous RT } \\
\text { Dose (Gy) }\end{array}$ & $\begin{array}{c}\text { Time to } \\
\text { failure (mo) }\end{array}$ & $\begin{array}{l}\text { Type of } \\
\text { failure }\end{array}$ & $\begin{array}{l}\text { Treatment for } \\
\text { recurrence }\end{array}$ & $\begin{array}{l}\text { Current } \\
\text { status }\end{array}$ \\
\hline MO & $\mathrm{F} / 40$ & Extremity (U) & 10 & + & 60 & 165 & infield & Surgery & NED, Followed-up \\
\hline EA & $\mathrm{F} / 17$ & Extremity (L) & 15 & + & 64 & 67 & infield & $\begin{array}{c}\text { Chemotherapy } \\
\text { Brachytherapy }+ \text { Surgery }\end{array}$ & NED, Followed-up \\
\hline IE & $\mathrm{M} / 10$ & Extremity (U) & 6 & + & 60 & 35 & infield & $\begin{array}{l}\text { Brachytherapy }+ \text { Surgery } \\
\text { (amputation) }+ \text { TMX }\end{array}$ & NED, Followed-up \\
\hline $\mathrm{HG}$ & $\mathrm{F} / 36$ & Retroperitoneal & 10 & + & 47.2 & 24 & infield & $\begin{array}{c}\text { TMX + Surgery (debulking) } \\
+ \text { EBRT }\end{array}$ & Lost to follow-up \\
\hline ET & $\mathrm{M} / 13$ & Extremity (L) & 10 & + & 50.4 & 8 & infield & Surgery + Brachytherapy & NED, Followed-up \\
\hline EK & $\mathrm{M} / 10$ & Extremity (L) & 10 & + & 46 & 3 & outfield & Surgery (amputation) + EBRT & NED, Followed-up \\
\hline NS & $\mathrm{F} / 45$ & Extremity (L) & 8 & + & 66 & 33 & outfield & Surgery + EBRT & Lost to follow-up \\
\hline RK & $\mathrm{F} / 46$ & Extremity (U) & 7 & - & 46 & 71 & infield & Surgery + Chemotherapy & Lost to follow-up \\
\hline OT & $\mathrm{F} / 19$ & Extremity (L) & 5 & + & 54 & 13 & infield & Surgery & NED, Followed-up \\
\hline
\end{tabular}

NED: no evidence of disease; U: upper; L: lower; M: male; F: female; RT: radiotherapy; y: year; mo: month; cm: centimeter; Gy: gray; TMX: tamoxifen; EBRT: external beam radiotherapy

CT or MRI of the involved region were repeated every 3-6 months for 2-3 years, then every 6 months up to 5 years and annually thereafter. Further investigative studies were done according to the patients' complaints. Local failure was confirmed by a biopsy sample. Recurrent disease was defined as in field or out of field.

Statistical analysis was performed using the SPSS software program (Version 16.0, IBM, New York, USA). Local control rate was estimated using the Kaplan-Meier method. Time to local recurrence was calculated from the last day of radiotherapy to date of relapse. Univariate analysis on locoregional control was evaluated by using the log-rank test. Statistically, $\mathrm{p}$ values level $<0.05$ were considered significant. Multivariate analysis was not performed because of the small sample size of this study. Acute and late side effects of radiotherapy were recorded and graded according to the Radiation Oncology Group (RTOG) acute and late morbidity scoring criteria. Since this was a retrospective analysis, our institutional board was informed before the analysis, which was conducted in accordance with the principles of the deceleration of Helsinki and the rules of Good Clinical Practice. National rules do not require ethical committee approval to be obtained for retrospective studies. Also, written informed consent was obtained from all patients who participated in this study.

\section{RESULTS}

The median follow-up of all patients was 77.5 months (range: $28-283$ months). Nine patients (45\%) developed lo- cal recurrence. Time to local recurrence ranged from 3-165 months (median 33 months). The local control (LC) rate at 2 years was $80 \%$ and at 5 years was $69 \%$. Eight of the 9 patients had positive surgical margins. Seven recurrences $(78 \%)$ were in field, while 2 were out of radiation field. Four of the 5 patients who received less than 54 Gy had in-field recurrences. Eight local failures $(89 \%)$ occurred in patients with extremity lesions.

All patients with local relapse underwent salvage surgery and 2 of them had amputations. Three of the 9 patients underwent external re-irradiation and 3 patients were treated with brachytherapy. Systemic treatment was given to patients who had more than one recurrence. Two patients were treated with chemotherapy and two patients had Tamoxifen (Mylan Pharmaceuticals Inc. Morgantown, U.S.A.). However, 3 patients relapsed more than 2 times after salvage treatment. These patients were re-operated upon. Six patients were followed without evidence of disease; 3 patients were lost to follow-up, two after 2 years, and one after 1 year. Details of patients who developed recurrence are summarized in Table 2.

On univariate analysis, the 5 year local control rate was significantly better for the patients irradiated with $\geq 54$ Gy than for patients irradiated with $<54 \mathrm{~Gy}(\mathrm{p}=0.023)$. Tumor size, tumor site and presentation status were not significantly associated with local control. The LC rate at 5 years was $80 \%$ in patients with a negative surgical margin and $53 \%$ in patients with positive surgical margins. However, the difference was not statistically significant $(\mathrm{p}=0.16)$ (Table 3 ).

The most common radiation-related acute side effects were skin effects. Grade 1 acute dermatitis occurred in $55 \%$ of the patients and 7 patients had grade 2 acute dermatitis. As a late 
TABLE 3. Univariate analyses of prognostic factors for local control

\begin{tabular}{|c|c|c|c|}
\hline & $\mathrm{n}$ & $\begin{array}{l}\text { ar local co } \\
\text { rate (\%) }\end{array}$ & $\mathrm{p}$ \\
\hline \multicolumn{4}{|l|}{ Tumor size } \\
\hline$\geq 10 \mathrm{~cm}$ & 10 & 70 & \multirow[t]{2}{*}{0.76} \\
\hline$<10 \mathrm{~cm}$ & 10 & 70 & \\
\hline \multicolumn{4}{|l|}{ Tumor site } \\
\hline Extremity & 11 & 62 & \multirow{3}{*}{0.17} \\
\hline Axial & 7 & 86 & \\
\hline Hand-foot & 2 & 50 & \\
\hline \multicolumn{4}{|l|}{ Dose } \\
\hline$<54$ Gy & 5 & 40 & \multirow[t]{2}{*}{0.02} \\
\hline$\geq 54$ Gy & 15 & 79 & \\
\hline \multicolumn{4}{|l|}{ Surgical margin status } \\
\hline Negative & 5 & 80 & \multirow[t]{2}{*}{0.16} \\
\hline Positive or close & 12 & 53 & \\
\hline \multicolumn{4}{|l|}{ Presentation } \\
\hline Recurrent disease & 16 & 67 & \multirow[t]{2}{*}{0.92} \\
\hline Primary disease & 4 & 75 & \\
\hline
\end{tabular}

side effect of radiotherapy, soft tissue fibrosis was detected in 10 patients and lymphangitis was seen in 1 patient. One patient developed radiation-induced sarcoma after 14 years and underwent an amputation. During follow-up, two patients died of non-tumor-related causes (metastatic renal cell cancer and cardiac failure).

\section{DISCUSSION}

Desmoid tumors are histologically benign but locally aggressive neoplasms. It is a heterogeneous disease and has various different biological behaviors. It infiltrates adjacent tissues and may lead to symptoms due to deformation and organ dysfunction. The management of desmoid tumors is controversial and the optimal therapy is still not clear $(3,5,7)$.

Complete surgical resection is usually the standard treatment in patients with resectable desmoid tumors, especially in extraabdominal desmoid tumors. However, it is not always possible to perform wide local excision $(17,18)$. The local recurrence rate is still high after resection alone due to its infiltrative pattern. Some investigators have reported a recurrence rate of $20-90 \%$ in literature (9-12). The reason for the high rate of local relapse is still unclear but surgical resection margin is thought to be the most effective factor. In several studies, it has been reported that positive surgical margin significantly influences local recurrence rates, while others have not demonstrated any association (1921). In a retrospective series, the probability of recurrence was reported to be $20-30 \%$ in patients with a negative resection margin, and $50-90 \%$ after incomplete surgical resection $(21,22)$. In our study, LC rate was superior for patients with negative surgical margins than positive margins ( $80 \%$ vs $53 \%$ ); however, the difference was not significant, which may be related to the small and unbalanced sample size. There are some series showing considerable correlation between tumor localization and surgical margin $(21,22)$.

Several prognostic factors such as age, gender, tumor location and tumor size have been reported to play a role in the local control of the disease in literature $(10,16,23,24)$. In the study by Melis et al. (21), extremity lesions were associated with an increased recurrence. The local control rate was better in axial tumors than extremity tumors ( $86 \%$ vs. $62 \%)$ in our series; however, the results were not statistically significant $(\mathrm{p}=0.17)$. Also, the literature reported that desmoids were rare in the young and in the elderly. In our study, the median age was 29 years and 7 patients were under 18 years old. However, we could not show any association between tumor size, tumor site, presentation, age and prognosis.

Radiotherapy is another treatment modality for desmoid tumors but its efficiency is controversial $(14,24,25)$. It has been used both in the primary setting for inoperable tumors or in the adjuvant setting after inadequate surgery. In the Rare Cancer Network database, it has been reported that when radiotherapy was applied alone and combined with surgery, local control rates were better than surgery alone. The administration of radiotherapy after surgery was an independent positive prognostic factor for local control and progression-free survival (6). The most recently published meta-analysis and the review by Nuyttens also showed that surgical resection alone had a higher local recurrence rate compared to radiotherapy alone or surgery with radiation. According to the meta-analysis, the best local control was ensured by a combined surgery and radiation $(9,18)$.

In Nuyttens' review, including 22 retrospective studies, it was demonstrated that the recurrence rates significantly decreased if radiotherapy was added postoperatively, especially in cases with positive margin after surgery. Postoperative radiotherapy was effective for both primary and recurrent disease (9). In this study, $80 \%$ of the patients presented with recurrence and underwent radiotherapy for recurrent disease. The 5 year local control rate was $67 \%$ in patients who referred us after recurrence and $75 \%$ in patients treated for primary tumors $(\mathrm{p}=0.92)$.

At present, to ensure local control, the optimal dose of radiation is not known. There is a little evidence for a dose-response relationship. In retrospective series, the suggested dose was 50 to $55 \mathrm{~Gy}$ for subclinical or gross disease (26). A retrospective 
study from the Massachusetts General Hospital demonstrated a significant difference in LC rates in patients with gross disease who received more than 60 Gy (20). Nuyttens and colleagues reported that 102 patients were treated by sole radiotherapy with 50-60 Gy and local control rate was 78\% (9). In the multicentric, prospective phase II EORTC (62991) trial which was the first prospective study for this issue, 44 patients with inoperable disease of primary, recurrent or incompletely resected lesions received 56 Gy. They reported that the 3 year LC rate was $81.5 \%$. Acute and late side effects were acceptable (27). In our series, the only significant factor for local control was radiotherapy dose. The local control rate was better for patients who received an RT dose $\geq 54$ Gy than for patients who received $<54$ Gy. The 5 year local control rate in patients received $\geq 54$ Gy was $79 \%$, which is comparable with the literature.

Currently, some investigators also suggested an observation for stable and asymptomatic lesions since it has a slowly growing pattern and/or may spontaneously regress $(7,15,16,23)$. In a recently published study, the authors declared that approximately $50 \%$ of patients with desmoid tumors benefit from non-aggressive treatment approaches. They suggested a wait and see policy at the beginning and then medical treatment if appropriate. If there is progression, surgery and/or RT should be the subsequent choice. Therefore, the unnecessary complications of radiotherapy and surgery may be avoided (25-27). Others have recommended chemotherapy or systemic therapy (such as hormonal therapy, non-steroidal anti-inflammatory therapy or targeted therapy) in patients with advanced unresectable tumors or recurrent disease after surgery and/ or radiotherapy. However, there has been no controlled randomized trial in this setting. The influence of chemotherapy in the treatment of the desmoid tumors is unclear and limited $(2,7,18,28)$. However, some retrospective series and the French sarcoma group study demonstrated good outcomes with chemotherapy (29). On the other hand, hormonal therapy is the most commonly used non-cytotoxic chemotherapy mentioned in the literature. There are reports that desmoids tumors are responsive to anti-estrogen treatment. It is considered that there is relationship between sex steroid hormone, especially estrogen and tumor growth in some of the desmoids, as they are seen in young women during pregnancy. Recently, Deyrup et al. (30) demonstrated that extra-abdominal desmoid tumors express estrogen receptor- $\beta$ (ER- $\beta$ ). That may play a role in the clinical activity of anti-estrogen treatment. In our study, due to tumor recurrence, 2 patients were treated with chemotherapy and 2 patients received Tamoxifen. Stable response was obtained in all patients after the treatment.

In summary, surgery is still the primary treatment modality for patients with resectable desmoid tumors. Adjuvant radiotherapy is required for incomplete resection. According to our results, radiotherapy is especially beneficial in recurrent disease. We observed a higher local control rate with the use of a radiotherapy dose more than $54 \mathrm{~Gy}$. In the future, understanding the etiology and molecular pathogenesis of desmoid tumors may change the treatment decisions such as a nonaggressive approach (wait and see policy, systemic therapy or targeted therapy).

\section{Ethics Committee Approval: N/A.}

Informed Consent: Written informed consent was obtained from patient who participated in this study.

Peer-review: Externally peer-reviewed.

Author contributions: Concept - F.Ö.D., D.Ç.Ö.; Design - F.Ö.D., Ş.A.E., D.Ç.Ö.; Supervision - F.Ö.D., D.Ç.Ö., S.K.; Resource - S.D., M.H., N.M.M.; Materials - Ş.A.E., E.E.T.; Data Collection and/or Processing - Ş.A.E., E.E.T., D.Ç.Ö.; Analysis and/or Interpretation - Ş.A.E., D.Ç.Ö., F.Ö.D.; Literature Search - E.E.T., Ş.A.E.; Writing - Ş.A.E., E.E.T., D.Ç.Ö.; Critical Reviews - F.Ö.D., S.D., N.M.M., M.H., S.K.

Conflict of Interest: No conflict of interest was declared by the authors.

Financial Disclosure: The authors declared that this study has received no financial support.

\section{REFERENCES}

1. Alman BA, Pajerski ME, Diaz-Cano S, Corboy K, Wolfe HJ. Aggressive fibromatozis (desmoids tumor) is a monoclonal disorder. Diag Mol Pathol 1997;6:98-101. [CrossRef]

2. Bonvalot S, Desai A, Coppola C, Le Péchoux C, Terrier P, Dömont J, et al. The treatment of desmoid tumors: a stepwise clinical approach. Ann Oncol 2012;23 Suppl 10:158-66. [CrossRef]

3. Shinagare AB, Ramaiya NH, Jagannathan JP, Krajewski KM, Giardino AA, Butrynski JE et al. A to Z of Desmoid Tumors. AJR Am J Roentgenol 2011;197:1008-14. [CrossRef]

4. Häyry P, Reitamo JJ, Tötterman S, Hopfner-Hallikainen D, Sivula A. The desmoid tumor. II. Analysis of factors possibly contributing to the etiology and growth behavior. Am J Clin Pathol 1982 Jun;77:674-80. [CrossRef]

5. Lewis JJ, Boland PJ, Leung DHY, Woodruff JM, Brennan MF. The enigma of desmoid tumors. Ann of Surg 1998;229:866-73. [CrossRef]

6. Baumert BG, Spahr MO, Von Hochstetter A, Beauvois S, Landmann $\mathrm{C}$, Fridrich K, et al. The impact of radiotherapy in the treatment of desmoids tumours. An international survey of 110 patients. A study of the Rare Cancer Network. Radiation Oncology 2007;2:1-12. [CrossRef]

7. Kasper B, Ströbel P, Hohenberger P. Desmoid Tumors: Clinical features and treatment options for advanced disease. The Oncologist 2011;16:682-93. [CrossRef] 
8. Rutenberg MS, Indelicato DJ, Knapik JA, Lagmay JP, Morris C, Zlotecki RA, et al. External beam radiotherapy for pediatric and young adult desmoid tumors. Pediatr Blood Cancer 2011;57:435-42. [CrossRef]

9. Nuyttens JJ, Rust PF, Thomas CR, Turrisi AT 3rd. Surgery versus radiation therapy for patients with aggressive fibromatosis or desmoids tumors: A comparative review of 22 articles. Cancer 2000;88:1517-23. [CrossRef]

10. Ballo M, Zagars GK, Pollack A, Pisters PWT, Pollock RA. Desmoid Tumor: Prognostic factors and outcome after surgery, radiation therapy or combined surgery and radiation therapy. $J$ Clin Oncol 1999;17:158-67.

11. Shido Y, Nishida Y, Nakashima H, Katagiri H, Sugiura H, Yamada Y. et al. Surgical treatment for local control of extremity and trunk desmoid tumors. Arch Orthop Trauma Surg 2009;129:929-33. [CrossRef]

12. Peng PD, Hyder O, Mavros MN, Turley R, Groeschi R, Firoozmand A, et al. Management and recurrence patterns of desmoid tumors: A multi-institutional analysis of 211 patients. Ann Surg Oncol 2012;19:4036-42. [CrossRef]

13. Zlotecki RA, Scarborough MT, Morris CG, Berrey BH, Lind DS, Enneking WF, et al. External beam radiotherapy for primary and adjuvant management of aggressive fibromatosis. Int $\mathrm{J} \mathrm{Ra}$ diat Oncol Biol Phys 2002;54:177-81. [CrossRef]

14. Jelinek JA, Stelzer KJ, Conrad E, Bruckner J, Kliot M, Koh WJ, et al. The efficacy of radiotherapy as postoperative treatment for desmoid tumors. Int J Radiat Oncol Biol Phys 2001;50:121-5. [CrossRef]

15. Fiore M, Rimareix F, Mariani L, Domont J, Collini P, Péchoux CL, et al. Desmoid-type fibromatosis: a front-line conservative approach to select patients for surgical treatment. Ann Surg Oncol 2009;16:2587-93. [CrossRef]

16. Salas S, Dufresne A, Bui B, Blay JY, Terrier P, Vince DR, et al. Prognostic factors influencing progression-free survival determined from a series of sporadic desmoid tumors: a waitand-see policy according to tumor presentation. J Clin Oncol 2011;29:3553-8. [CrossRef]

17. Pakos EE. Tsekeris PG, Goussia AC. Desmoid tumours of the extremities and trunk: a review of the literature. Int Orth 2005;29:210-3. [CrossRef]

18. Wood TJ, Quinn KM, Farrokhyar F, Deheshi B, Corbett T, Ghert MA. Local control of extra-abdominal desmoid tumors: systematic review and meta-analysis. Rare Tumors 2013;5:5-10. [CrossRef]
19. Bölükbaş1 Y, Kamer S, Anacak Y, Aras A. The Role of Radiotherapy in the Management of Patients with Aggressive Fibromatosis. UHOD 2007; 17: 31-6.

20. Spear M.A., Jennings L.C., Mankin H.J., Spiro I.J., Springfield M.D., Gebhardt M.C., et al. Individualizing management of aggressive fibromatoses. Int $J$ Radiat Oncol Biol Phys 1998;40:637-45. [CrossRef]

21. Melis M, Zager JS, Sondak VK. Multimodality of desmoid tumors: How important is a negative surgical margin ? J of Surg Oncol 2008;98:594-602. [CrossRef]

22. Gluck I, Griffith KA, Bierman JS, Feng FY, Lucas DR, BenJosef E. Role of radiotherapy in the management of desmoid tumors. Int J Radiat Oncol Biol Phys 2011;80:787-92. [CrossRef]

23. Bonvalot S, Eldweny H, Haddad V, Rimareix F, Missenard G, Oberlin O, et al. Extra-abdominal primary fibromatosis: Aggressive management could be avoided in a subgroup of patients. Eur J Surg Oncol 2008;34:462-8. [CrossRef]

24. Ozger H, Eralp L, Toker B, Ağaoğlu F, Dizdar Y. Evaluation of prognostic factors affecting recurrences and disease-free survival in extra-abdominal desmoid tumors. Acta Orthop Traumatol Turc 2007;41:291-4.

25. Goy BW, Lee SP, Eilber F, Dorey F, Eckardt J, Fu YS, et al. The role of adjuvant radiotherapy in the treatment of resectable desmoid tumors. Int J Radiat Oncol Biol Phys 1997;39:659-65. [CrossRef]

26. McGinn CJ. Chapter:76 Soft tissue sarcomas (excluding retroperitoneum). In: Perez CA, Brady LW, Halperin AC, Schmidt-Ullrich RK., editors. Principles and Practice of Radiation Oncology. Fourt edition, USA: Lippincott Williams \& Wilkins, 2004. p.2200.

27. Keus R.B., Nout R.A., Blay J.Y., de Jong J.M., Hennig I., Saran F., et al. Results of a Phase II pilot study of moderate dose radiotherapy for inoperable desmoids-type fibromatosis - an EORTC STBSG and ROG study (EORTC 62991-22998). Annals of Oncology 2013;24:2672-6. [CrossRef]

28. Camargo V.P., Keohan M.L., D'Adamo D.R., Antonescu C.R., Brennan M.F., Singer S., et al. Clinical outcomes of systemic therapy for patients with deep fibromatoses (desmoid tumors). Cancer 2010;116:2258-65.

29. Garbay D., Le Cesne A., Penel N., Chevreau C., Marec-Berard P., Blay J.Y., et al. Chemotherapy in patients with desmoid tumors: a study from the French Sarcoma Group (FSG). Ann Oncol 2012;23:182-6. [CrossRef]

30. Deyrup AT, Tretiakova M, Montag AG. Estrogen receptor-beta expression in extraabdominal fibromatoses: an analysis of 40 cases. Cancer 2006;106:208-13. [CrossRef] 